\title{
Power and Rights in the Community: Paralegals as Leaders in Women's Legal Empowerment in Tanzania
}

\author{
Helen Dancer ${ }^{1}$ (D)
}

Published online: 31 March 2018

(C) The Author(s) 2018

\begin{abstract}
What can an analysis of power in local communities contribute to debates on women's legal empowerment and the role of paralegals in Africa? Drawing upon theories of power and rights, and research on legal empowerment in African plural legal systems, this article explores the challenges for paralegals in facilitating women's access to justice in Tanzania, which gave statutory recognition to paralegals in the Legal Aid Act 2017. Land conflicts represent the single-biggest source of local legal disputes in Tanzania and are often embedded in gendered land tenure relations. This article argues that paralegals can be effective actors in women's legal empowerment where they are able to work as leaders, negotiating power relations and resisting the forms of violence that women encounter as obstacles to justice. Paralegals' authority will be realised when their role is situated within community leadership structures, confirming their authority while preserving their independence.
\end{abstract}

Keywords Access to justice $\cdot$ Legal empowerment $\cdot$ Legal pluralism · Paralegals · Tanzania $\cdot$ Women's land rights

\section{Introduction}

The presence of paralegals within African justice systems forms part of a decadeslong, worldwide access to justice movement to make rights effective, especially for the poor and marginalised (Cappelletti et al. 1982). Over the past 15 years, legal empowerment agendas have increasingly embraced paralegals as a policy solution

Helen Dancer

H.E.Dancer@sussex.ac.uk

1 School of Law, Politics and Sociology, University of Sussex, Falmer, Brighton BN1 9QE, UK 
for facilitating access to justice in countries with limited or no legal aid provision. In a number of African countries civil society organisations train local volunteers as paralegals to act as a bridge between the professional legal world and the local community, to advise and assist their fellow citizens to address legal problems within the community, to educate and raise awareness of legal rights and procedures, and to mediate disputes. In most African countries, however, paralegal programmes are at an early stage of development. Moreover, to date there has been very little research to assess the effectiveness of paralegal programmes for women's legal empowerment in Africa (Jacobs et al. 2011; Kapur 2011; Behrman et al. 2013; Billings et al. 2014; Massay 2016; Mueller et al. 2017). This article explores two issues that are particularly significant for women's legal empowerment: gendered power relations in plural legal systems and the role of paralegals in the community. It draws on feminist scholarship on power and rights, as well as empirical research on land disputes and recent studies on paralegal schemes in Tanzania. Taking a fresh perspective on the role of paralegals, it develops a theoretical model for understanding how paralegals interact with local leadership structures, and the role they could play in their engagement with the justice system to empower women.

The potential of paralegals to facilitate access to justice for poor and marginalised groups is widely acknowledged, and their contribution to criminal and civil legal aid is now recognised in United Nations and African regional soft law instruments (Dereymaeker 2016, 7-11). ${ }^{1}$ However, paralegals' effectiveness has often been limited by a lack of official status and regulatory frameworks, power dynamics within community spheres, the potential for abuse of paralegals' role and functions, and limited funding capacity (Dereymaeker 2016; Gauri and Maru 2017). The issue of statutory recognition of paralegals within justice systems remains unresolved in many cases. This is partly because at an international level, there is no universally accepted definition of paralegal and they have no formal status in international law. At a local level, tensions can arise through lack of acceptance or recognition of paralegals when such interventions clash with pre-existing local leadership structures. Paralegals also suffer from lack of recognition in professional legal spheres. Currently, no African countries authorise paralegals to represent litigants in courts, in spite of this recommendation being made in the 2003 United Nations (UN) Principles and Guidelines on a Fair Trial and Legal Assistance in Africa.

This article focuses on Tanzania following the country's recent enactment of the Legal Aid Act No. 1 of 2017, which established a new regulatory framework for legal aid and statutory recognition of paralegals. Tanzania is the third African country after Sierra Leone and Nigeria to formally recognise the role of paralegals in statute, and a number of other countries are poised to join them. ${ }^{2}$ Historically,

\footnotetext{
1 These include the African Commission on Human and Peoples' Rights Dakar Declaration 1999; Lilongwe Declaration on Accessing Legal Aid in the Criminal Justice System in Africa 2004; United Nations General Assembly Principles and Guidelines on a Fair Trial and Legal Assistance in Africa 2003, and Access to Legal Aid in Criminal Justice Systems 2012. The 2012 Kampala Declaration on Community Paralegals is the first African regional tool dedicated specifically to paralegals.

2 A survey of 11 African countries shows that in countries where paralegals lack statutory status they still tend to be located within national legal aid frameworks, which often comprise government institutions, law clinics and civil society organisations (Dereymaeker 2016).
} 
in the few places in Tanzania where paralegal schemes had been established by civil society organisations, their effectiveness was reported to be limited because their role received little recognition from the legal profession and society generally (Peter 1997, 341; WLAC 2007; Diehl 2009). However, the landscape of paralegal provision in Tanzania began to shift dramatically from 2012, when the Legal Services Facility was established by the Tanzanian government with Danish funding to provide financial support to legal aid organisations in Tanzania. Since then the Legal Services Facility has been rolling out paralegal programmes across the country, building on earlier initiatives of the Women's Legal Aid Centre, HakiArdhi, the Legal and Human Rights Centre and other Tanzanian civil society organisations. ${ }^{3}$

Empirical evidence from Tanzania suggests that the problem of local recognition of paralegals may not be fully resolved by the model provided in the recent statute. This article analyses the local social, legal and political context in which paralegals work and explores an alternative model for recognition of their leadership role. It focuses particularly on land conflicts, which represent the leading legal problem in Tanzanian communities (LSF 2012). African and broader feminist approaches are used to develop a theoretical framework for understanding how gender, power and rights affect women's access to justice and the role that community leaders play in this process. This presents particular obstacles for both women litigants and paralegals when power is manifested through different forms of violence during the course of a legal dispute.

The first part of this article discusses the policy discourses surrounding legal empowerment in African plural legal systems, what it is considered to mean, and why a focus on power relations is necessary for realising women's land rights and access to justice. The second part analyses the relationship between gender, power and rights, and the forms of violence that accompany the exercise of power in legal disputes. The third part contextualises this analysis in my own empirical research on women's claims to land (Dancer 2015) and other empirical research, policy studies and practitioner reports on community-based legal aid and paralegal schemes in Tanzania (Diehl 2009; Behrman et al. 2013; Billings et al. 2014; LSF 2015; Massay 2016; Mueller et al. 2017). Theorising a model of local power relations and leadership, it is argued that paralegals are likely to be most effective in mobilising rights and facilitating women's access to justice where they are recognised and embedded as leaders in their own right. The challenge then becomes how to design paralegal schemes that preserve paralegals' independence, while enabling them to work effectively within the dynamics of local leadership structures and power relations in the community.

\footnotetext{
${ }^{3}$ In 2014 around 40,000 clients were served and 90,000 persons reached with legal and human rights education. By 2015, basic legal aid services had been funded in all 168 districts and over 4000 functional paralegals had completed their training or were in the process of doing so (LSF 2015).
} 


\section{Legal Empowerment in African Legal Systems}

Legal empowerment, as policy makers currently use the term, is commonly traced back to a (2001) Asian Development Bank publication by Golub and McQuay and is particularly associated with a report Making the Law Work for Everyone produced for the UN Commission on the Legal Empowerment of the Poor (CLEP 2008). It has been promoted by various international organisations including The Open Society Justice Initiative, US AID, the UN Food and Agriculture Organisation, the International Development Law Organization, Namati and the World Bank. Over the past 15 years, in order to address the limited availability of legal aid for ordinary citizens, African governments and civil society organisations have been working with these international organisations and a number of overseas governments to develop legal empowerment programmes in Africa. There has been a particular focus on paralegal initiatives, which are now widely seen as a solution for legal empowerment in countries where legal aid services for the poor have historically been severely under-resourced.

There has been significant debate surrounding what legal empowerment actually means and the normative commitments that legal empowerment policies entail. CLEP defines it as 'a process of systemic change through which the poor and excluded become able to use the law, the legal system, and legal services to protect and advance their rights and interests as citizens and economic actors' (2008, 3). Two alternative perspectives, which Ubink and van Rooij interpret from the various international policy sources refer to, on the one hand, legal tools 'used to empower marginalized citizens and attain greater control over the decisions and processes that affect their lives'. Alternatively, the concept is used to refer to activities 'undertaken to tackle power asymmetries that undermine the effective functioning of legal tools for marginalized citizens, preventing access to justice and ultimately their development' (Ubink and van Rooij 2011, 17). These legal tools or activities represent policy solutions designed to facilitate access to justice for the poor. At the community level, paralegals often work as facilitators under the umbrella of civil society organisations in the implementation of legal empowerment initiatives.

CLEP policies largely follow the legal tools interpretation, which reflects a human rights-based view of how law is used, placing emphasis on information provision and legal education for the poor. Parallel development discourses on the empowerment of women and girls more generally, have also tended to emphasise capacity-building of the individual in various social, economic and political contexts. Described by Kabeer (1999) as beginning with an awakening of 'the power within', most development interventions on women's empowerment have, until quite recently, focused largely on how women themselves may overcome patriarchal oppression. However, as Cornwall and Nyamu-Musembi argue, the intentions of many externally driven human rights-based agendas for 'empowerment' may also serve to entrench neo-colonialism in the process. This is because they are based on a normative conception of human rights that is fundamentally different from the roots of African struggles for rights against all forms of oppression, 
including imperialist oppression (Mamdani 1996; Manji 1998; Nyamu-Musembi 2004; Cornwall and Nyamu-Musembi 2004). This means that development agencies engaged in rights-based approaches need to be critically self-aware of their normative standpoint and the inherent power inequalities in their work (Cornwall and Nyamu-Musembi 2004, 1432).

It is important to see this normative approach in full historical context. From an anthropological perspective, Nader (2002) argues that present international law and development policy represents the continuation of a colonial project that began with attempts to consolidate local norms and social practices into what became labelled 'customary law' (Chanock 1985). She argues it has continued into the present through on-going interventions by American and European governments to transplant idealised versions of Western legal frameworks and the rule of law in other parts of the world. Nader characterises this contemporary use of law as a political instrument as 'legal engineering', which in many cases has not sufficiently taken into account the culture of 'receiver societies' (2002, 60-67). There are neoliberal agendas underpinning these Western political interventions since the 1990s, which have also had important implications for gender equality and women's rights activism. From an African feminist perspective, Nyamu-Musembi argues that in the post-Cold War epoch, Western governments and international economic institutions focused on the rule of law as a necessary precondition for establishing a market economy and democratic rule. However, until more recently, they gave limited attention to legal issues that are critical for realising social justice and women's rights, including reform of personal laws in pluralist legal settings. The consequence was few substantive gains for gender equality (Nyamu-Musembi 2006, 1194). International funding of African women's rights NGOs has also influenced their approach to activism. Tamale has argued that the African women's movement itself needed to change by confronting its 'de-politicisation' in the face of donor-driven agendas (2006): 'While the top-down constitutional and legal framework is necessary as a foundational touchstone of women's rights, our activism must begin from the assumption that bottom-up approaches anchored in local cultures and traditions are more likely to succeed than those working from without' (Tamale 2008, 64; see also Butegwa 2002). Together, these critiques point out that certain externally-driven legal empowerment agendas may in fact risk undermining African women's struggles for rights by promoting a depoliticised approach.

Critics of individualistic approaches to human rights and empowerment also point to the need to deal with the power asymmetries embedded within social, economic and political structures (Kabeer 2005; Cornwall and Rivas 2015). These concerns are addressed in Ubink and van Rooij's second interpretation of legal empowerment. However, these authors argue that they have received insufficient attention in the design and implementation of many internationally initiated legal empowerment programmes (Ubink and van Rooij 2011; Carmona and Donald 2015). This in part reflects a lack of consensus over whether law itself represents a tool of empowerment (Sage et al. 2009) or disempowerment for the poor (Golub 2009; Domingo and O'Neil 2014; Waldorf 2015, 230). Rights-based approaches lean towards the former. For example, while recognising the role and importance of customary and traditional justice systems in local communities, 
the 2008 CLEP interpretation adopts a state-centralist approach to strengthening access to justice in plural legal contexts. It does so by using the principle of the rule of law and statutory regulatory frameworks as a touchstone, and the provisioning of legal services as the mechanism for strengthening the capacity of the poor to make legal claims.

Cultural realities and the disempowering side of an idealised notion of the rule of law are brought to bear through people's experiences of using justice systems in practice. Scholars who have reflected on this side of the rule of law focus particularly on the inequalities of power that shape legal processes (Cotula 2007, 113; Cotula and Mathieu 2008; van de Meene and van Rooij 2008, 15). The Kiswahili expression sheria ni msumeno ('law is a saw') is a metaphor that encapsulates this tension in the rule of law. It evokes an image of law as a double-edged saw: a productive tool that cuts both ways, representing both the principle of the rule of law and its sharpness. It serves as a tool to literally 'cut a case' kukata kesi, but also, to be cut by. To extend this metaphor a little further, in practice those who have the social, financial or educational resources can use this saw to assert their rights through litigation. Conversely, those who lack power or resources to make effective use of the saw may find it turned against them. In such circumstances, law may be little more than a blunt or weak tool of last resort (Dancer 2015, 46). Feminist scholars writing on African legal systems have drawn attention to the differences between women and men's experiences of law and legal processes in practice. Ethnographic studies of local courts in Botswana, Kenya and Tanzania have found gendered discourses and power relations in the community to be reproduced through court processes, particularly where customary and religious norms concerning land, marriage and inheritance are concerned (Griffiths 1997; Hirsch 1998; Dancer 2015).

Ubink and van Rooij's second interpretation of legal empowerment goes to the root of this deeper issue of how power asymmetries affect the way law is used in practice. It is this second, activities approach, which calls for a more substantive notion of understanding the ways people try to access justice and why power relations matter. More recently, legal pluralism scholars, and some international development organisations, have turned attention to how to strengthen access to justice and the rights of marginalised social groups in the context of customary justice systems. In African plural legal systems, traditional (or customary) justice systems interact with state legal systems. The relationship between these systems, the role of traditional leaders and the recognition of customary justice by states vary considerably. However, it is countries with these kinds of plural legal systems that have been the focus of 'customary legal empowerment' initiatives in Africa. Moving away from the legal tools approach, these customary legal empowerment initiatives have engaged communities themselves in debates around local norms and social practices and their interaction with constitutional rights (Golub 2010; Ubink 2011a, b, c, d). The normative underpinnings of these initiatives have included promoting social inclusivity, gender equity and community consensus (Ubink 2011a, b, c, d). It could be argued that these programmes share some of the features of 'legal engineering'. However, their decentring of the role of the state and attention to local context and power relations means that local communities and marginalised groups within them retain power in the decision-making process and outcomes. 
In spite of the fact that some legal empowerment programmes, as described above, have focused on structural issues surrounding power asymmetries, most mainstream legal empowerment programmes have been oriented towards developing the capacity or agency of individuals and marginalised groups to help themselves. This may include work around legal aid provision, but it is primarily concerned with equipping citizens with the knowledge and tools to engage with legal systems (Golub 2010; Waldorf 2015). However, a fundamental challenge for litigants and those who support them is how to negotiate existing power relations in realising their rights. The more recent programmes for customary legal empowerment have paid greater attention to the impact of power relations on norms and community structures. In both kinds of programmes, constitutional rights have been seen as potential sources of empowerment for citizens, either as tools for capacity-building, or as normative frameworks to advocate for change in local customary laws, where they are in conflict.

\section{Gender, Power and Rights in Plural Legal Systems}

The limitation of most legal empowerment programmes in pluralist legal contexts is that they focus on the user of legal services, while failing to give sufficient attention to the power relations that constitute barriers to justice. The reality of women's experiences of making claims to land in these contexts is that gendered power relations are embedded within customary law and local legal structures. The challenge for women claimants, and those who support them, is how to effectively negotiate these power relations in practice. Analysing the way power spreads through legal systems in the community draws attention to how actors-particularly local leaders-affect women's claims to land and access to justice in practice. This in turn offers a theoretical framework for placing legal empowerment and paralegal programmes in social, legal and political context. This section draws upon African and broader feminist scholarship, and Foucault's theories on power and rights, to develop an analysis of gender, power and rights in African plural legal systems. This provides a theoretical basis for analysing the capacity of paralegals to act within local networks of capillary power.

Foucault's theories of capillary power (Foucault 1980) and the relationship between power and rights (Foucault 1977-1978) are a useful starting-point for analysing approaches to legal empowerment. His theory of rights is instrumentalist, but it is also qualified by the principle that individual subjectivity is constituted as the effect of power and rights. Foucault argues that rights claims are simultaneously constructed and constrained by laws, norms, power relations and social structures. As Golder notes, for Foucault the instrumentalist value of rights is always contingent, representing at once a 'truth-weapon' of social struggle and a 'tool for political organisation': for the individual they are a tool that cannot be controlled or mastered (Golder 2015, 90-113). Foucault's theory of the contingent nature of rights demonstrates the weakness of the tools approach to legal empowerment and why it is necessary to bring attention to power relations. However, to understand women's experiences of power and rights, Foucault's theoretical framework needs to be 
supplemented with an understanding of the structural privilege of men (Butler 1990; Ramazanoğlu 1993).

Feminist scholars writing on power and rights in African legal systems have argued that the privileging of legal centralism and state law is itself phallocentric. Manji observes that to understand women's 'legal world' therefore requires engagement with legal pluralism, because women have distanced themselves from the coercive power of state law based on a legal world experienced by men (Manji 1999, 451). Manji theorises why, in pluralist legal settings, even where women's claims have the backing of state law, communities may deny statutory entitlements or sometimes sanction women's claims to land in spite of norms that do not support this. Claims are not only determined by an individual's position in society or by rules of entitlement as to what they can legitimately command [Sen's (1982) original 'entitlement' model]. Her 'modified entitlement model' takes into account that communities are producers of law and norms in their own right — and apply them flexibly. Women also impact upon, transform and undermine norms when making claims (Manji 2000). In Kenya, Musila observes women's response to the 'phallocentrism' of the state as being one of 'gynocratic contestation' (Musila 2009, 2012).

A further dimension of feminist analysis is the prevalence of violence in legal disputes. MacCannell and MacCannell argue from a victim's perspective that in male-dominated social structures capillary power is accompanied by capillary violence, backed by authority. Violence takes various forms, whether direct (including verbal and physical abuse), legal and/or bureaucratic (including false accusations, black-listing and abuse of regulations), or administrative (including over-zealous, sadistic or authoritarian execution of office) (MacCannell and MacCannell 1993). However, little attention is given within legal empowerment discourses to the connection between gender, power and violence in plural legal systems. A recent psychological study by Grabe et al. examined the relationship between institutional and interpersonal power and violence in the context of women's land ownership in Tanzania and Nicaragua. Using data from 492 women, the findings show reduced levels of physical and psychological violence where women own land in regions where land ownership is associated with dominance (Grabe et al. 2015). This also helps to explain why, in legal systems that are embedded in patriarchal social relations, women and men experience the effects of violence differently. While the legal tools approach to legal empowerment pays insufficient attention to the politics of rights and power relations in practice, the activities approach does not fully confront the gendered systemic challenges faced by women in resisting violence. Drawing upon empirical research from Tanzania, it is argued here that making legal empowerment programmes effective for women turns on addressing the relationship between power and violence that affect women's access to justice in practice. This approach goes beyond mainstream policy discourses. It argues that paralegals themselves will only be empowered to facilitate women's access to justice through changes in their position as actors working across intersecting social, political and legal spheres.

This raises questions concerning the position and power of paralegals within the community. What is their source of authority? How should they work with already established leaders? What makes them effective leaders within the communities they serve? Writing on gender power, leadership and governance, Duerst-Lahti 
and Kelly point out that leadership, like governance, is inherently relational and involves influence of followers, tasks or culture (Duerst-Lahti and Kelly 1995, 12). 'Gender power' is another aspect of leadership, which can be defined as 'power and power dynamics resulting from the practices of people performing gender within the normative constraints gender modes impose' (Duerst-Lahti and Kelly 1995, 20). Together, gender, power and leadership are mutually reinforcing. Duerst-Lahti and Kelly (1995) argue that the perception of power grants an individual an advantage in being accepted as a leader. If one is a leader, one is more likely to be seen as powerful. Because in most communities men have more social power and hold more political leadership posts, they benefit more in the relationship between leadership and power. This means that quotas for women in leadership roles are not in themselves an adequate solution. Leaders must also have social power. The next part analyses the way gender, power and leadership work in the resolution of land disputes and the implications this has for legal empowerment.

\section{Gender, Power and Leadership in Tanzanian Land Disputes}

It is commonly acknowledged that women's claims to land in African plural legal systems are made in a context of gendered land tenure relations and leadership structures (Whitehead and Tsikata 2003). Several Tanzanian and other East African studies have documented the significance of power and the role of local leaders in land disputes and women's access to justice (Moore 1986; Manji 2000; Nyamu-Musembi 2002; Odgaard and Bentzon 2007; Ikdahl 2008; Henrysson and Joireman 2009; Corradi 2011; Dancer 2015; Anying and Gausset 2017). All of these studies support the view that (mostly male) family and community leaders often become pivotal actors in facilitating or obstructing women's access to justice.

In Tanzania, people can acquire land in different ways, each embedded in its own set of power relations. During a year of ethnographic research conducted in Arusha, Tanzania between 2009 and 2010, I explored the ways in which gendered power relations become manifested when women make legal claims to land (Dancer 2015). Family and clan land is inherited or transferred inter vivos through patrilineal or matrilineal descent practices. Executive power features in the allocation of land by village governments under the Land Act and Village Land Act of 1999 ('the Land Acts'). Power relations between spouses affect the way women and men acquire and register land individually or jointly through purchase or lease, or by clearance and cultivation. Each mode of acquisition confers on the occupier of the land corresponding legal rights and social duties concerning use and disposition. Where village land is passed between the generations of a family, gendered and intergenerational customary tenure relations are constructed over the land. These customary ties restrict dispositions without the consent of key family members and village leaders involved in land administration.

Tanzania's Land Acts locate responsibility for governance of land at a village level through village councils. Village and ward executive officers play an important role as both members of local government development committees and overseers of the workings of local land tribunals. Their roles straddle both executive and 
judicial branches of local government. This means that social power relations over land within families are also situated in local political and legal power structures where executive and judicial powers are fused. In village communities, local community leaders (balozi and mwenyekiti wa kitongoji) are elected by the residents of a street or sub-area within a village to deal with a range of administrative and dispute resolution duties. These are political posts that date back to the $1960 \mathrm{~s}$, instituted by the then socialist ruling party TANU as 'a source of continuous political vigilance' following an attempted coup in 1964 (Moore 1986, 372). These leaders mediate disputes within a community and are also called upon as amicus curiae by village and ward tribunals in the adjudication of land disputes. They confirm boundaries to the land and interests in the land in communities where land registration is still uncommon. They may be influential decision-makers in land tenure matters and may have close connections with adjudicators in land tribunals at village or ward level. It is not uncommon for these local community leaders to be appointed subsequently as ward tribunal members.

These power relations intersect social, political and legal spheres in a local community. They therefore raise challenges for litigants, particularly women, who must negotiate the micropolitics of patriarchy embedded within local land tenure and legal systems. In the context of women's legal claims to land power and violence often combine. The case studies from Arusha, Tanzania (Dancer 2015) reveal various forms of violence at the hands of litigants, family and community members, local leaders and officials. These range from cursing, intimidation and false criminal claims, to the destruction of crops and physical assaults, to bribery and manipulation of legal and administrative processes.

This is the context in which Tanzania's paralegals are operating. The statutory duties of paralegals in Tanzania are set out in Part IV of the Legal Aid Act 2017. These include carrying out educational programmes on legal issues and procedures of concern to the community; assisting legally aided persons with obtaining necessary legal documents, and guiding them to access justice; and advising conflicting parties to seek amicable settlement or referring them to dispute settlement institutions. The Act therefore places special emphasis on the pacific and educational role of paralegals, and as with other countries, it does not give paralegals the authority to represent litigants in court. It requires all paralegals to undergo a regulated training programme and to possess as a minimum a bachelor's degree (but not in law), a diploma or certificate from an accredited institution, or a certificate of secondary education. This limits the pool of potential candidates, particularly in rural areas. Currently only $2 \%$ of adults over 18 years of age in Tanzania have completed Form IV education, and 9\% have reached Form III (Tanzania NBS 2012; Billings et al. 2014). The Act gives paralegals state-backed recognition to carry out their role by requiring qualified paralegals who are trained under a registered legal aid provider to be registered with the Registrar of Legal Aid Providers. However, it does not include a local level structure to build and sustain trust and legitimacy of paralegals within the community and with local leaders. This is a critical step if paralegals are to be able to challenge and resist violence in dispute resolution.

Figure 1 models the way in which local social, legal and political spheres intersect in practice. In this model, under the Legal Aid Act 2017 paralegals are well 


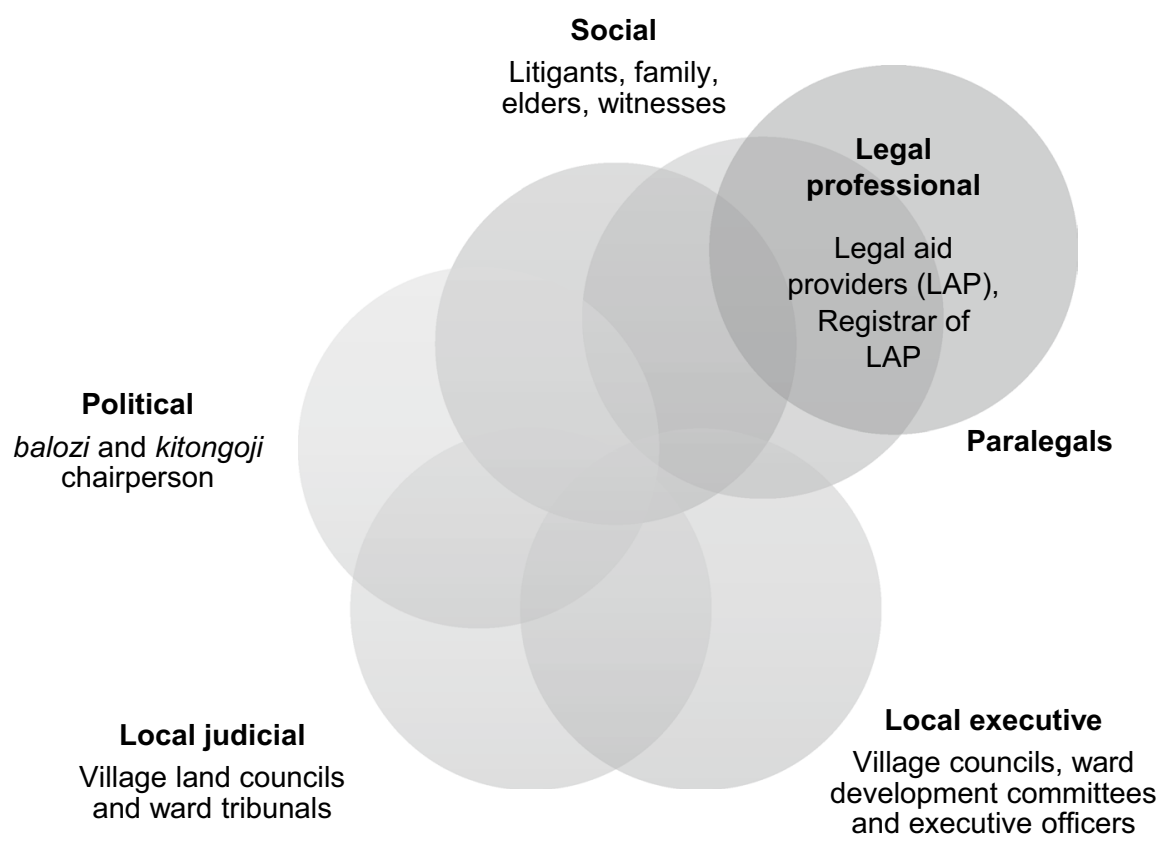

Fig. 1 Paralegals and local power relations following the Legal Aid Act 2017

connected to the legal aid providers and legal professionals outside the local community, and to their fellow citizens who elect them. However, the requirement of independence from other political, legal and executive roles also makes them less influential, less embedded in pre-existing power networks, and often less accepted by other community leaders.

Research from Tanzania suggests that the degree to which community leaders accept the position of paralegals as rights advocates, has an important bearing on their effectiveness in carrying out their role. Empirical research conducted at Morogoro Paralegal Centre in the south of Tanzania in 2005 observed instances of paralegals being criticised as activists and reproached within their communities for not respecting the culture. They were not generally regarded as neutral mediators, but as advertently trying to strengthen a certain set of norms (Diehl 2009). Mueller et al. (2017) found that a 1-year community-based legal aid programme in Kagera, Tanzania had only limited short-term impact in changing local attitudes and practices towards women's land rights. Behrman et al. report an overwhelming consensus among implementing organisations that it is important to identify people who are already well-respected, accepted by local leaders, and active in their communities as paralegals (Behrman et al. 2013, 37). A 2016 report on community training of 'land rights monitors' (LRMs) by the Tanzanian land rights organisation HakiArdhi also illustrates the challenges of community level recognition for legal rights volunteers since 2012. HakiArdhi currently supports around 600 LRMs in 300 villages across Tanzania. The role of 
LRMs is similar to that of a paralegal, but with a specific focus on land rights issues. It includes community training, giving access to justice advice and support to villagers, and providing links to HakiArdhi and lawyers at the Legal and Human Rights Centre. A man and woman are elected by their community at the end of a capacity-building exercise that includes district councillors, ward leaders, members of the village council, and villagers (Massay 2016). Massay highlights achievements by some LRMs, including in promoting women's land rights through facilitating discussion between spouses and encouraging women villagers to participate more in public decision-making processes. However, despite these successes, he also reports a high drop-out rate of around half of LRMs, due to lack of commitment, changes in personal circumstances, discouragement or lack of support from village leaders, and conflict-related risks to personal safety. Women LRMs face specific gender-based risks of harassment and sexual assault, and many have been prevented from carrying out their role due to other household responsibilities and lack of support from their husbands (Massay 2016, 8).

The strategic goal of the Tanzania Legal Services Facility is 'increasing access to justice for all, in particular for women' (LSF 2015). The challenges of discouragement and harassment faced by women LRMs and paralegals in particular, is all the more significant because the Legal Services Facility's research has found that women seek paralegal services more than men-the suggestion being that women face more problems than men, particularly gender-based discrimination and harmful traditional practices. The proposal is therefore, that women should account for at least half if not $60 \%$ of trained paralegals in Tanzania. Billings et al. similarly found gender balance to be important, with each sex indicating a preference for talking to people of the same sex (Billings et al. 2014). However, to be able to facilitate women's access to justice effectively, paralegals of both sexes must not only be able to give good legal advice and timely referral to a legal aid clinic. They must also be able to act as community leaders who can negotiate the various forms of power and violence that obstruct pathways to justice.

The challenge of recognition and acceptance of paralegals by local leaders is acknowledged in the 2015 strategic plan of the Legal Services Facility (LSF 2015). It notes that in many parts of the country local leadership prevails, and incidences of collaboration between village executive officers (VEOs), ward executive officers (WEOs) and paralegals are very much the exception. In spite of this, legal empowerment has been presented optimistically as not a threat to authority but as 'an opportunity for leaders to engage in communal decision making with a positive buy-in of all stakeholders' (LSF 2015, 16). District trainers are to play a role in sensitising local leaders that:

...there is no conflict of interest between them and community based paralegals, but that a win-win situation can be created for everybody at district, ward and village level... Paralegals are to focus on involving informal local leadership, like clan, religious leaders and other influential community representatives and should be provided with the resources for the purpose, which includes the ability to conduct meetings or even small local level workshops (LSF 2015, 18). 
As the empirical evidence suggests, it is the limits of their leadership within the community, which in turn limits their effectiveness in facilitating access to justice. In the case of women paralegals, Duerst-Lahti and Kelly's (1995) theory would suggest that both the gendered nature of local leadership structures and social practices of land tenure constitute limiting factors on women's social power as they perform gender within these normative constraints.

How could paralegals gain greater recognition as leaders within the community while maintaining their independence? Some lessons may be drawn from Sierra Leone, which is arguably the most successful African example where paralegals have been able to play an effective role in facilitating access to justice. Paralegals are formally recognised in the Legal Aid Act No. 6 of 2012 as part of the broader legal aid framework, and are appointed to each Chiefdom by the Legal Aid Board in open, participatory processes involving local authorities and interest groups. Their role and relationship with established local leaders is also prescribed under section 14 (2) of that Act: to 'provide advice, legal assistance and legal education to the Paramount Chief and the inhabitants of the Chiefdom; and (b) where appropriate, to assist in diverting certain cases to the formal justice system' (Dereymaeker 2016, 18). Maru notes that when paralegals bring people together in community dialogue they build a forum where people can be both informed and encouraged to demand their rights, and leaders have an opportunity to meet their constituents $(2006,442)$. The effectiveness and legitimacy of their leadership in the community appears to stem from the composition of Community Oversight Boards (COBs). COBs supervise community-based paralegals and operate between the community and the supporting civil society organisation Timap for Justice. COB members are appointed in consultation with paramount chiefs, other chiefs and local organisations including women's and youth groups.

Sierra Leone's use of COBs offers one possible approach, which could be adapted to suit the local context of other countries. Figure 2 illustrates what such a model might look like in Tanzania. Here paralegals' external authority is derived from their statutory recognition, and by extension, their association with legal aid providers and the Registrar of Legal Aid Providers. To be able to work effectively within the community, this external recognition needs to be bridged with the community through on-going internal recognition. Figure 2 illustrates how power relationsand paralegals' position within the community-could be re-centred through the medium of an overseeing body that draws acceptance from key local constituencies.

The COB model from Sierra Leone would raise a number of challenges in the context of Tanzania. Political influence and the overlap of executive and judicial powers in local land governance has been a feature of Tanzanian local government since independence. While Tanzania is often recognised as having some of the most progressive land laws in Africa for gender equality, local administrative and court systems remain embedded in local politics and patriarchal social structures. Tanzania's Land Acts require female membership of land governance institutions, but this is not enough to deconstruct networks of male privilege. To be effective facilitators of women's legal empowerment and access to justice, paralegals-particularly women paralegals - need social and political legitimation not only among their fellow citizens, but also within local power relations and leadership structures. 


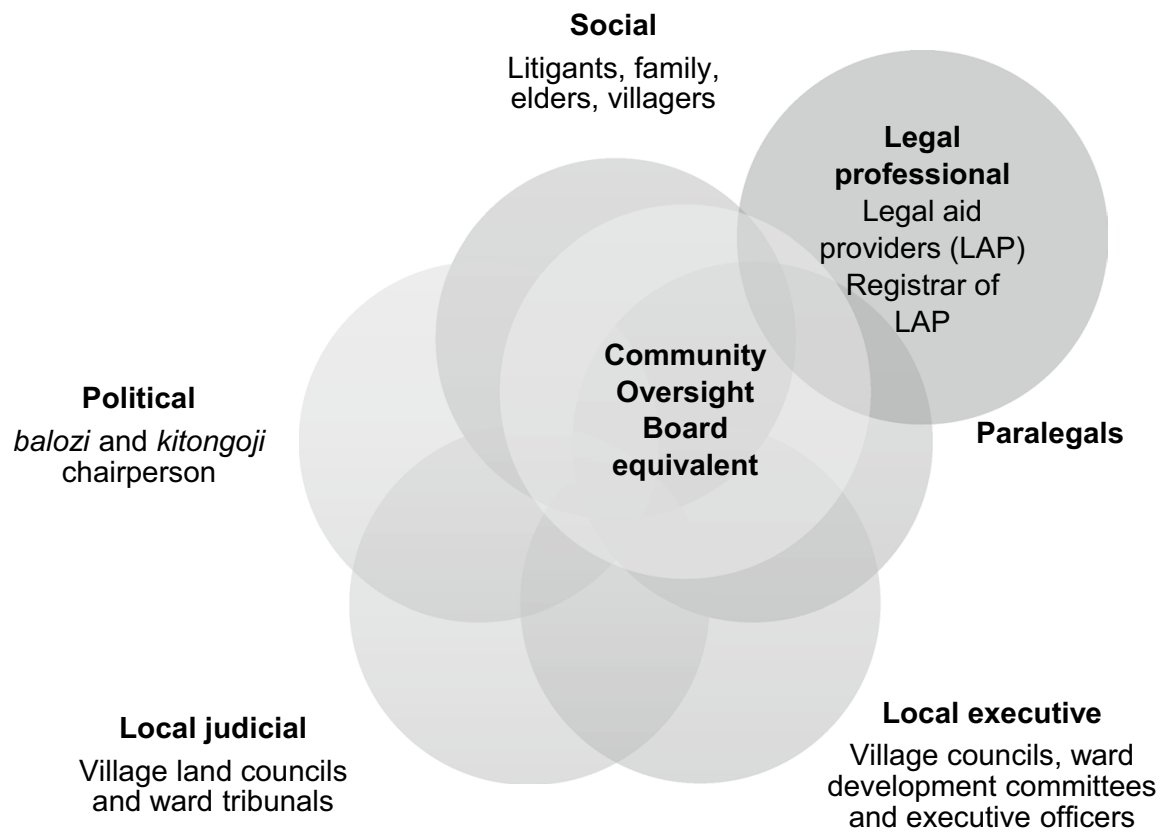

Fig. 2 Increasing recognition of paralegals within local leadership structures

Historically these have been entrenched in the power bases of the country's leading party.

\section{Conclusion}

Theories of power and rights and recent research on customary legal empowerment discussed here, all point towards the conclusion that effective legal empowerment requires addressing the way power relations and local leadership structures impact citizens' access to justice. However, the relationship between power, violence and leadership theorised by feminist scholars has received limited attention in policy debates on legal empowerment in African legal systems. The multiple forms of violence that women in particular experience when making legal claims to land, shows this relationship to be a critical factor in their ability to access justice and realise their rights. In plural legal systems, gendered customary land tenure relations and male-dominated local leadership structures set the scene for citizens' engagement in processes of land dispute resolution. African feminist scholars point out that women themselves have responded to the 'phallocentrism' of men's 'legal world' by distancing themselves from it (Manji 1999) or through 'gynocratic constestation' (Musila 2009, 2012). However, it is equally clear that without transforming this relationship between power, violence and leadership in 
the community, many women and the community paralegals that support them in making claims, will continue to face barriers to justice.

The effectiveness of paralegal initiatives depends on addressing an unresolved tension about where paralegals are situated within local power relations. In Tanzania, the Legal Aid Act 2017 requires paralegals to be independent from any other local political, judicial or executive office. They must be able to facilitate access to justice, if necessary, by challenging local power relations; but they cannot rely on the established authority that comes from being a community leader, precisely because of their relatively weak embeddedness in local power bases. The problem is compounded for women paralegals in a male-dominated system where gender, power and leadership are mutually reinforcing. This is borne out by the gender-based violence experienced by women Land Rights Monitors in Tanzania. Moreover, the high drop-out rate of paralegals in Tanzania suggests that capacity-building exercises and even an election process are not enough to establish paralegals as local leaders in their own right.

For paralegals to overcome these systemic challenges requires both internal and external recognition of their role in the community. While external recognition is relatively straightforward to achieve through statutory criteria and monitoring, internal recognition involves establishing an independent position of authority within pre-existing community leadership structures. For women, this also means establishing personal authority in a male-dominated system. The example of Community Oversight Boards in Sierra Leone offers one possible model for adaptation to local circumstances, and provides a structure for on-going dialogue with local leaders that recognises women and men paralegals as leaders in their own right. Many African feminists have argued that women's rights and access to justice in Africa are most likely to be realised ultimately through activism around local norms, cultures, traditions and community leadership. Equally, the challenge of developing internal community recognition structures also lies outside the community in the commitment of national governments to processes of change in local leadership. This is a political challenge, because in Tanzania, and in other African countries, executive power bases at national and local levels are interdependent. It is an important step for the national legislative to give statutory recognition to paralegals from outside their communities. Ultimately however, paralegals' internal recognition will be realised when national governments situate the role of paralegals as leaders within community power structures, confirming their authority while preserving their independence.

Acknowledgements This article is based on a paper written and presented during my time as a visiting scholar at the Center for the Study of Law and Society, University of California Berkeley, where I benefited from many inspiring discussions with colleagues. I give individual thanks to Laura Nader, Jonathan Simon, Janine Ubink, Kenneth Veitch, Godfrey Massay and two anonymous reviewers for their valuable comments on earlier versions of the article. My visiting scholarship at Berkeley was supported by a Santander travel grant award and research sabbatical from the University of Brighton.

Open Access This article is distributed under the terms of the Creative Commons Attribution 4.0 International License (http://creativecommons.org/licenses/by/4.0/), which permits unrestricted use, distribution, and reproduction in any medium, provided you give appropriate credit to the original author(s) and the source, provide a link to the Creative Commons license, and indicate if changes were made. 


\section{References}

Anying, Irene W., and Quentin Gausset. 2017. Gender and forum shopping in land conflict resolution in Northern Uganda. The Journal of Legal Pluralism and Unofficial Law 49: 353-372.

Behrman, Julia, Lucy Billings, and Amber Peterman. 2013. Evaluation of grassroots community-based legal aid activities in Uganda and Tanzania: Strengthening women's legal knowledge and land rights. In CAPRi working paper no. 108. Washington, DC: International Food Policy Research Institute.

Billings, Lucy, Ruth Meinzen-Dick, and Valerie Mueller. 2014. Implications of community-based legal aid regulation on women's land rights. Research BRIEF No. 20. Washington, DC: International Food Policy Research Institute.

Butegwa, Florence. 2002. Mediating culture and human rights in favour of land rights for women in Africa: A framework for community level action. In Cultural transformation and human rights in Africa, ed. Abdullahi A. An-Naim, 108-125. London: Zed.

Butler, Judith. 1990. Gender trouble: Feminism and the subversion of identity. London: Routledge.

Cappelletti, Mauro, Bryant Garth, and Nicolò Trocker. 1982. Access to justice, variations and continuity of a world-wide movement. The Rabel Journal of Comparative and International Private Law 46 Jahrg. H. 4: 664-707.

Carmona, Magdalena Sepúlveda, and Kate Donald. 2015. Beyond legal empowerment: Improving access to justice from the human rights perspective. The International Journal of Human Rights 19: 242-259.

Chanock, Martin. 1985. Law, custom and social order: The colonial experience in Malawi and Zambia. Cambridge: Cambridge University Press.

CLEP. 2008. Making the law work for everyone. New York: Commission on Legal Empowerment of the Poor and UNDP.

Cornwall, Andrea, and Celestine Nyamu-Musembi. 2004. Putting the 'rights-based approach' to development into perspective. Third World Quarterly 25: 1415-1437.

Cornwall, Andrea, and Althea-Maria Rivas. 2015. From 'gender equality and 'women's empowerment' to global justice: Reclaiming a transformative agenda for gender and development. Third World Quarterly 36: 396-415.

Corradi, Giselle. 2011. Access to justice in Pemba City: How exploring women's lived realities with plural law uncovers programmatic gaps. The Journal of Legal Pluralism and Unofficial Law 43: 1-31.

Cotula, Lorenzo. 2007. Legal empowerment for local resource control: Securing local resource rights within foreign investment projects in Africa. London: International Institute for Environment and Development.

Cotula, Lorenzo, and Paul Mathieu (eds.). 2008. Legal empowerment in practice: Using legal tools to secure land rights in Africa. London: International Institute for Environment and Development.

Dancer, Helen. 2015. Women, land and justice in Tanzania. Woodbridge: James Currey.

Dereymaeker, Gwenaelle. 2016. Formalising the role of paralegals in Africa: A review of legislative and policy developments. Cape Town: Dullah Omar Institute (CSPRI), Open Society Justice Initiative and Paralegal Advisory Service Institute.

Diehl, Eva. 2009. Can paralegals enhance access to justice? The example of Morogoro Paralegal Centre in Tanzania. Verfassung und Recht in Übersee 42: 187-211.

Domingo, Pilar, and Tam O’Neil. 2014. The politics of legal empowerment: Legal mobilisation strategies and implications for development. London: Overseas Development Institute.

Duerst-Lahti, Georgia, and Rita Mae Kelly (eds.). 1995. Gender, power, leadership and governance. Ann Arbor: University of Michigan Press.

Foucault, Michel. 1977-1978 [2007] Security, territory, population: Lectures at the Collège de France 1977-78. (trans: Graham Burchell). Basingstoke: Palgrave Macmillan.

Foucault, Michel. 1980. Two lectures. In Power/knowledge: Selected interviews and other writings 19721977, ed. Colin Gordon, 78-108. London: Harvester.

Gauri, Varun, and Vivek Maru (eds.). 2017. Bringing law to life: Community paralegals and the pursuit of justice. Cambridge: Cambridge University Press.

Golder, Ben. 2015. Foucault and the politics of rights. Redwood City: Stanford University Press.

Golub, Stephen. 2009. The commission on legal empowerment of the poor: One big step forward and a few steps back for development policy and practice. Hague Journal of the Rule of Law 1: 105. 
Golub, Stephen (ed.). 2010. Legal empowerment: Practitioners' perspectives. Rome: International Development Law Organization.

Golub, Stephen, and Kim McQuay. 2001. Legal empowerment: Advancing good governance and poverty reduction. In Law and policy reform at the Asian Development Bank. 2001st ed, ed. Office of the General Counsel. Manila: Asian Development Bank.

Grabe, Shelly, Rose G. Grose, and Anjali Dutt. 2015. Women's land ownership and relationship power: A mixed methods approach to understanding structural inequities and violence against women. Psychology of Women Quarterly 39: 7-19.

Griffiths, Anne M.O. 1997. In the shadow of marriage: Gender and justice in an African community. Chicago: Chicago University Press.

Henrysson, Elin, and Sandra F. Joireman. 2009. On the edge of the law: Women's property rights and dispute resolution in Kisii, Kenya. Law and Society Review 43: 39-60.

Hirsch, Susan F. 1998. Pronouncing and persevering: Gender and the discourses of disputing in an African Islamic court. Chicago: University of Chicago Press.

Ikdahl, Ingunn. 2008. "Go home and clear the conflict": Human rights perspectives on gender and land in Tanzania. In Women's land rights and privatization in Eastern Africa, ed. Birgit Englert and Elizabeth Daley, 16-40. Woodbridge: James Currey.

Jacobs, Krista, Meredith Saggers, and Sophie Namy. 2011. How do community-based legal programs work? Understanding the process and benefits of a pilot program to advance women's property rights in Uganda. Washington, DC: International Center for Research on Women.

Kabeer, Naila. 1999. Resources, agency, achievements: Reflections on the measurement of women's empowerment. Development and Change 30: 435-464.

Kabeer, Naila. 2005. Gender equality and women's empowerment: A critical analysis of the third Millennium Development Goal 1. Gender \& Development 13: 13-24.

Kapur, Amrita. 2011. Two faces of change: The need for a bi-directional approach to improve women's land rights in plural legal systems. In Working with customary justice systems: Post-conflict and fragile states, ed. Erica Harper, 73-89. Rome: International Development Law Organization.

LSF. 2012. Baseline survey on Tanzania mainland and Zanzibar for legal services facility. Dar es Salaam: ST Associates.

LSF. 2015. Increasing access to justice for all, in particular for women: A strategy towards promotion and protection of human rights through legal empowerment. Strategy for 2016-2020. Dar es Salaam: Legal Services Facility.

MacCannell, Dean, and Juliet Flower MacCannell. 1993. Violence, power and pleasure: A revisionist reading of Foucault from the victim perspective. In Up against Foucault: Explorations of some tensions between Foucault and feminism, ed. Caroline Ramazanoğlu, 203-238. London and New York: Routledge.

Mamdani, Mahmood. 1996. Citizen and subject: Contemporary Africa and the Legacy of Late Colonialism. Princeton: Princeton University Press.

Manji, Ambreena. 1999. Imagining women's 'legal world': Towards a feminist theory of legal pluralism in Africa. Social \& Legal Studies 8: 435-455.

Manji, Ambreena. 2000. "Her name is Kamundage": Rethinking women and property among the Haya of Tanzania. Africa: The Journal of the International African Institute 70: 482-500.

Manji, Firoze. 1998. The depoliticisation of poverty. In Development and rights: Selected essays from development in practice, ed. Deborah Eade, 12-33. Oxford: Oxfam GB.

Maru, Vivek. 2006. Between law and society: Paralegals and the provision of justice services in Sierra Leone and Worldwide. Yale Journal of International Law 31: 427-476.

Massay, Godfrey. 2016. Pillars of the community: How trained volunteers defend land rights in Tanzania. London: International Institute for Environment and Development.

Moore, Sally Falk. 1986. Social facts and fabrications: “Customary” law on Kilimanjaro 1880-1980. Cambridge: Cambridge University Press.

Mueller, Valerie, Lucy Billings, Tewodaj Mogues, Amber Peterman, and Ayala Wineman. 2017. Filling the legal void? Impacts of a community-based legal aid program on women's land-related knowledge, attitudes, and practices. Oxford Development Studies. https://doi.org/10.1080/13600 818.2017.1414174.

Musila, Grace A. 2009. Phallocracies and gynocratic transgressions: Gender, state power and Kenyan public life. Africa Insight 39: 39-57. 
Musila, Grace A. 2012. Violent masculinities and the phallocentric aesthetics of power in Kenya. In The new violent cartography: Geo-analysis after the aesthetic turn, ed. Samson Okoth Opondo and Michael J. Shapiro, 151-170. London and New York: Routledge.

Nader, Laura. 2002. The life of the law: Anthropological projects. Berkeley: University of California Press.

Nyamu-Musembi, Celestine. 2002. Are local norms and practices fences or pathways? The example of women's property rights. In Cultural transformation and human rights in Africa, ed. Abdullahi A. An-Na'im, 126-150. London: Zed.

Nyamu-Musembi, Celestine. 2004. Towards an actor-oriented perspective on human rights. In Inclusive citizenship: Meanings and expressions, ed. Naila Kabeer, 31-49. London: Zed.

Nyamu-Musembi, Celestine. 2006. Ruling out gender equality? The post-Cold War rule of law agenda in Sub-Saharan Africa. Third World Quarterly 27: 1193-1207.

Odgaard, Rie, and Agnete W. Bentzon. 2007. Rural women's access to landed property: Unearthing the realities within an East African setting. In Human rights, plural legalities and gendered realities: Paths are made by walking, ed. Anne Hellum, Julie Stewart, Shaheen S. Ali, and Amy Tsanga, 202235. Harare: Southern and Eastern African Regional Centre for Women's Law/Weaver Press.

Peter, Chris Maina. 1997. Human rights in Tanzania: Selected cases and materials. Köln: Rüdiger Köppe Verlag.

Ramazanoğlu, Caroline (ed.). 1993. Up against Foucault: Explorations of some tensions between Foucault and feminism. London and New York: Routledge.

Sage, Caroline, Nicholas Menzies, and Michael Woolcock. 2009. Taking the rules of the game seriously: Mainstreaming justice in development-The World Bank's Justice for the Poor Program. In World Bank justice \& development working paper series no. 7. Washington, DC: World Bank.

Sen, Amartya. 1982. The right not to be hungry. In Contemporary philosophy, ed. Guttorm Floistad, 343-360. The Hague: Nijhoff.

Tamale, Sylvia. 2006. African feminism: How should we change? Development 49: 38-41.

Tamale, Sylvia. 2008. The right to culture and the culture of rights: A critical perspective on women's sexual rights in Africa. Feminist Legal Studies 16: 47-69.

Tanzania NBS. 2012. National panel survey 2010-2011. Dar es Salaam: National Bureau of Statistics. http://nbs.go.tz/catalog/index.php/catalog/15/accesspolicy. Accessed March 42018.

Ubink, Janine M. (ed.). 2011a. Customary justice: Perspectives on legal empowerment. Rome: International Development Law Organization and Van Vollenhoven Institute.

Ubink, Janine M. 2011b. Effectuating normative change in customary legal systems: An end to 'widow chasing' in Northern Namibia. In Land, law and politics in Africa: Mediating conflict and reshaping the state, ed. Jan Abbink, and Mirjam E. de Bruijn, 315-333. Leiden: African Studies Centre.

Ubink, Janine M. 2011c. Gender equality on the horizon: The case of Uukwambi Traditional Authority, Northern Namibia. In Working with customary justice systems: Post-conflict and fragile states, ed. Erica Harper, 51-71. Rome: International Development Law Organization.

Ubink, Janine M. 2011d. Stating the customary: An innovative approach to the locally legitimate recording of customary law in Namibia. In Customary justice: Perspectives on legal empowerment, ed. Janine M. Ubink, 131-150. Rome: International Development Law Organization and Van Vollenhoven Institute.

Ubink, Janine M., and Benjamin van Rooij. 2011. Towards customary legal empowerment: An introduction. In Customary justice: Perspectives on legal empowerment, ed. Janine M. Ubink, 7-27. Rome: International Development Law Organization and Van Vollenhoven Institute.

van de Meene, Ineke, and Benjamin van Rooij. 2008. Access to justice and legal empowerment: Making the poor central in legal development co-operation. Leiden: Leiden University Press.

Waldorf, Lars. 2015. Introduction: Legal empowerment in transitions. The International Journal of Human Rights 19: 229-241.

Whitehead, Ann, and Dzodzi Tsikata. 2003. Policy discourses on women's land rights in Sub-Saharan Africa: The implications of the re-turn to the customary. Journal of Agrarian Change 3: 67-112.

WLAC. 2007. WLAC annual report for 2007: Access to justice through paralegal work. Dar es Salaam: Women's Legal Aid Centre. 